Thorax 1985;40:150-151

\title{
Acute pleural effusions in inactive ankylosing spondylitis
}

\author{
WJM KINNEAR, JM SHNEERSON \\ From Addenbrooke's Hospital, Cambridge
}

Apical pleural thickening in ankylosing spondylitis is common in association with apical fibrobullous disease.' Pleural disease is otherwise rare. We report a patient with ankylosing spondylitis and quiescent joint disease who developed bilateral pleural effusions.

\section{Case report}

A 47 year old toolmarker presented in 1982 with a two day history of bilateral pleuritic pain. He was not breathless and had no cough. For three weeks he had noted mild diarrhoea, weight loss, and malaise. A clinical and radiological diagnosis of ankylosing spondylitis had been made in 1964 but his joint disease had been quiescent for 18 years, requiring only occasional non-steroidal antiinflammatory drugs. Recurrent episodes of uveitis had resulted in impaired visual acuity. At the age of 10 years the patient had been in contact with tuberculosis; a tuberculin test had given a positive result and he was not given BCG. He had been otherwise well.

On examination his temperature was $38^{\circ} \mathrm{C}$ there was dullness to percussion at both lung bases and bilateral pleural rubs were available. Spinal movements were severely restricted in all directions but there were no other abnormal findings. The chest radiograph showed small bilateral pleural effusions. Radiographs of the patient's hands showed juxta-articular erosions and those of his spine showed spondylitis and obliteration of the sacroiliac joints. Laboratory investigations showed: haemoglobin concentration $9.8 \mathrm{~g} / \mathrm{dl}$, white cell count $19.1 \times 10 / 1$, (neutrophils $13 \cdot 4$, lymphocytes $4 \cdot 5$ ), erythrocyte sedimentation rate $80 \mathrm{~mm}$ in one hour. Concentrations of urea electrolytes, glucose, and uric acid and the results of liver function tests were normal; the albumin concentration was $18 \mathrm{~g} / \mathrm{l}$, calcium $2.04 \mathrm{mmol} / \mathrm{l},(8.2 \mathrm{mg} / 100 \mathrm{ml}) \mathrm{IgG} 22.5 \mathrm{~g} / \mathrm{l}$ (IgA and IgM were normal). The result of the RoseWaaler test was negative, and lupus erythematosus cells and autoantibodies were not detected. Urine, stool, and blood cultures were normal and paired viral titres negative. A 1/1000 Mantoux test gave a positive result. Barium meal and enema and rectal biopsy appearances were normal. The HLA type was A2, A11, B15, B27.

The patient subsequently became breathless and developed a pericardial rub. A repeat chest radiograph showed larger pleural effusions but a normal cardiac silhouette. Diagnostic pleural aspiration yielded straw coloured fluid with a protein concentration of $35 \mathrm{~g} / \mathrm{l}$; pus cells

Address for reprint requests: Dr WJM Kinnear, Newmarket General Hospital, Newmarket, Suffolk CB8 7JG.

Accepted 1 September 1984 were present but Gram staining and culture were negative. Tubercle bacilli were not seen in the fluid or grown on culture. A pleural biopsy was not performed. A diagnosis of inflammatory pleural effusion was made and treatment was started with prednisolone $30 \mathrm{mg} /$ day. The pyrexia resolved within 48 hours and the pericardial rub became $G$ inaudible. Over the course of the subsequent month the $\mathrm{O}$ pleural effusions also resolved and the steroids were gradually reduced.

\section{Discussion}

The spinal disease in the patient with HLA B27 is diagnostic of ankylosing spondylitis, to which we suggest the pleural effusions were related. Although ankylosing spon- of dylitis and rheumatoid arthritis have been reported together in a single patient, ${ }^{2}$ the negative serological results in the present case make coincidental rheumatoid arthritis unlikely and erosive peripheral joint disease may occur in ankylosing spondylitis. ${ }^{1}$ There was no evidence of current tuberculous or non-tuberculous infection.

Reviewing thoracic disease in ankylosing spondylitis in 1950, Dudley-Hart et al $^{3}$ commented on two patients with a post history of pleurisy, one of whom had a pleural effusion. Zorab ${ }^{4}$ in 1962 mentioned one tuberculous and one non-tuberculous effusion in 53 cases of ankylosing spondylitis, and in 1974 Crompton et al $^{\mathbf{5}}$ noted bilateral pleural calcification unrelated to tuberculosis or asbestos exposure $O$ in two of 255 cases of ankylosing spondylitis. Reviewing $\underset{x}{\sim}$ the radiographs of 2080 cases of ankylosing spondylitis $\bar{\sigma}$ Rosenow et al found non-apical pleural disease in 103 patients, but this was not an uncommon finding in their control subjects; two of these patients also had apical $\frac{0}{3}$ fibrobullous disease and in one extensive pleural thickening had resulted in cor pulmonale.' Three of the 2080 cases had pleural exudates with normal pleural fluid glucose con- $D$ centrations, and two of these had apical parenchymal disease; one further patient had an empyema. Spencer $e t a l^{6} \mathrm{~N}$ reported one patient with bilateral pleural thickening in $\sigma$ 200 cases of ankylosing spondylitis. There is no record in $N$ any of these reports of the temporal relationship between $\mathrm{N}$ activity of the joint and pleural disease, or of the response $\sigma$ to treatment. Pericarditis is another rare association of ankylosing spondylitis and this responds well to steroids. ${ }^{7}$ A recent survey ${ }^{8}$ has suggested that in the absence of $\mathbb{D}$ ankylosing spondylitis the presence of HLA B27 may be ? associated with an increased frequency of pleurisy and $\tau$ spontaneous pneumothorax.

We believe this is a further instance of pleural effusion complicating ankylosing spondylitis. The patient presented $\overrightarrow{\mathbb{D}}$ acutely 18 years after any evidence of active arthritis and the effusions resolved completely after steriod treatment. 
This is a rare association compared with apical parenchymal disease, but should not be overlooked as a further cause of breathlessness in patients with ankylosing spondylitis.

We would like to thank Dr G Neale for permission to report a patient under his care, and Alison Wilson for secretarial help.

\section{References}

1 Rosenow EC, Strimlan CV, Muhm JR, Ferguson RH. Pleuropulmonary manifestations of ankylosing spondylitis. Mayo Clin Proc 1977;52:641-9.

2 Lavery HA, Horner T, Roberts SD. Rheumatoid arthritis, ankylosing spondylitis and Reiter's syndrome occurring simultaneously. $\mathrm{Br} J$ Vener Dis 1982;58:196-9.

3 Dudley-Hart F, Bogdanovitch A, Nichol WD. The thorax in ankylosing spondylitis. Ann Rheum Dis 1950;9:116-31.

4 Zorab PA. The lungs in ankylosing spondylitis. $Q J$ Med 1962;31:267-80.

5 Crompton GK, Cameron SJ, Langlands AO. Pulmonary fibrosis, pulmonary tuberculosis and ankylosing spondylitis. Br J Dis Chest 1974;68:51-6.

6 Spencer DG, Park WM, Dick HM, Papazoglou SN, Buchanan WW. Radiological manifestations in 200 patients with ankylosing spondylitis: correlation with clinical features and HLA B27. J Rheumatol 1979;6:305-15.

7 Baites JE, Tucker JB, Baldwin JL, Thomas CN. Pericarditis in ankylosing spondylitis. $J$ Rheumatol 1980; 7:929-31.

8 Hillerdal G, Safvenberg J. HLA B27: risk factor for lung disease? Lancet 1983;ii: 1195. 